\title{
A APOSTA NA FILOSOFIA
}

\author{
Márcio Suzuki* \\ marciosuzuki@usp.br
}

RESUMO Para Hume, filosofar é uma atividade semelhante às demais ocupações humanas. A decisão que leva à atividade filosófica é menos resultado de uma argumentação teórica do que fruto de um cálculo prático, que é entendido como uma caça ou um jogo. O objetivo deste trabalho será $o$ de mostrar que no jogo filosófico perde quem joga sério demais. $A$ aposta na filosofia tem que passar pelo bom humor e pela diversão: uma resposta a Pascal?

Palavras-chave natureza humana, instinto, paixão, inquietude, jogo, aposta

ABSTRACT For Hume, philosophy is in itself neither more nor less important than other human activities. On the contrary, it can be explained from its resemblance with game and hunting. If one chooses to dedicate himself to philosophy, his decision is not the consequence of logical reasoning, but depends on practical evaluation, which has something to do with gambling. The following text tries to show that in philosophy, like in other games, the loser will be the one who plays too earnestly. The philosophical game requires good humour and some relaxation: Is this a good answer to Pascal's pari?

Keywords human nature, instinct, passion, uneasiness, game, gambling

* Professor do Departamento de Filosofia da USP. Artigo recebido em 06/11/2011 e aprovado em 26/11/2011.

KRITERION, Belo Horizonte, no 124, Dez./2011, p. 307-330. 
Trabalhar é menos tedioso do que se distrair. Friedrich Nietzsche, KSA 13, 11 [194]

Qual é a natureza da filosofia para David Hume? Pode-se de algum modo caracterizá-la segundo os parâmetros de uma ou algumas das “seitas" filosóficas do passado, ou ela representa um tipo de fazer filosófico inteiramente novo? Eis a questão para a qual dificilmente se poderá dar uma resposta única e definitiva.

Com efeito, o ensaio sobre o "Surgimento e Progresso das Artes e Ciências" afirma claramente que, com o renascimento das letras, nenhuma das seitas antigas pode voltar a ter de novo "algum crédito ou autoridade", por outro lado, os ensaios sobre o platônico, o epicurista, o estoico e o cético, sem pretender fidelidade às opiniões das escolas antigas, querem apresentar os "sentimentos" dessas seitas que "se formam naturalmente no mundo", sustentando "ideias diferentes sobre a vida e a felicidade humana". ${ }^{2} \mathrm{O}$ texto sobre o cético é, sem dúvida, o mais interessante sob esse aspecto, porque introduz uma série de particularidades que não se ajustam de todo ao figurino conhecido do ceticismo. Uma constatação se impõe: a natureza humana não é por princípio avessa nem ao estoicismo, nem ao epicurismo, nem tampouco ao platonismo. O problema dos sistemas filosóficos está menos neles mesmos do que em sua conversão numa obsessão monomaníaca, quando querem instaurar um estilo de vida pautado por um único padrão. É preciso se opor em bloco a esse tipo de uniformização da conduta, já que somente a "variedade" ou "judiciosa mistura" (judicious mixture) é o que torna agradáveis os diferentes "tipos de vida" (kinds of life). ${ }^{3}$

Em seu artigo sobre o pirronismo e a crítica de Hume ao pirronismo, Richard H. Popkin aponta uma característica do ceticismo humiano que merece reflexão. Segundo ele, para o pirrônico clássico não há como não aderir às "aparências" e viver conforme as regras normais da vida, pois não é possível permanecer inteiramente "inativo"; o pirronismo humiano teria apresentado uma "forma radical da doutrina antiga", porque, ao dizer que a natureza impele o homem à ação, ele teria sido levado a "aceitar muito mais" do que fariam os antigos. ${ }^{4} \mathrm{O}$ erro do pirronismo ortodoxo é querer se manter

1 HUME, D. "Do Surgimento e Progresso das Artes e Ciências". In: A Arte de Escrever Ensaio. São Paulo: lluminuras, 2011, p. 93. Os ensaios de Hume serão citados por essa tradução.

2 Idem, "O Epicurista", p. 107.

3 Idem, "O Cético", p. 128.

4 Popkin, R. H., "David Hume: His Pyrrhonism and His Critique of Pyrrhonism". In: The Philosophical Quartely, vol. 1, n. 5, oct. 1951, pp. 403-404. 
não-dogmático o tempo inteiro e a qualquer custo, suspendendo o juízo ali onde a natureza ensina o contrário. E tal atitude ferrenha o impede de chegar à paz de espírito, somente alcançada pelo cético humiano. ${ }^{5}$

Popkin enumera corretamente os dados do problema, mas o modo como enuncia a equação não deixa entrever quais as relações e os limites entre ceticismo e natureza. Como explicar, afinal, a ligação existente entre a atividade a que a natureza impele e a "paz de espírito"? E será que ainda faz sentido falar em "tranquilidade da alma"? O que parece frustrar as tentativas de explicar a filosofia de Hume unicamente pela via cética (ou por qualquer outra) é que, seja qual for a radicalidade ou a moderação da doutrina, ela não parece dar conta da sua filosofia como um todo, isto é, no conjunto de seus aspectos teóricos, éticos, políticos e estéticos.

Num estudo publicado como comentário à sua tradução de parte do Livro I do Tratado da Natureza Humana, Michel Malherbe fala da existência de dois tipos de ceticismo em Hume, um "para filósofos" e outro que diz respeito à natureza humana. A dificuldade estaria justamente no balanceamento dessas duas tendências, para o qual não haveria "verdadeira solução". Apesar da conclusão aporética, Malherbe aponta com razão que o ceticismo não atua aqui como uma "tese adversa", mas como uma afecção que age sobre o temperamento. Não há, para ele, separação absoluta entre filosofia e vida comum, pois a filosofia é uma "tendência que pode se tornar uma disposição". ${ }^{6}$

De fato, como a filosofia pode se tornar uma disposição? Uma boa maneira de compreender isso é refazendo o percurso da Conclusão do Livro I do Tratado, que Michel Malherbe chama de "um romance filosófico". Nesse romance, o narrador em primeira pessoa (o próprio Hume) passa de um ceticismo radical, mas carrancudo, a um ceticismo moderado e de bom humor. A passagem que leva de um a outro é escandida em três movimentos, e o que a torna possível não é a suspensão de juízo, mas a própria natureza.

O primeiro movimento é o da dúvida radical. A dúvida cética em relação aos sentidos e à razão, diz o Tratado, "é uma doença que jamais pode ser radicalmente curada, mas em que sempre recaímos, por mais que a afastemos, e por mais que algumas vezes pareçamos completamente livres dela". $\mathrm{O}$ momento mais crítico dessa enfermidade cética, natural e renitente como o

5 Idem, p 405.

6 MALHERBE, M. “Un roman philosophique”, in: Hume, D. Système sceptique et autres systèmes. Paris, Seuil, 2002, p. 81 e segs.

7 HUME, D. A Treatise of Human Nature. Edição de Selby-Bigge revisada por P. H. Nidditch. Oxford: Clarendon Press, 1978. I, IV, 2, p. 218. Tradução de Déborah Danowski. São Paulo: Unesp - Imprensa Oficial, 2000, p. 251. (A partir daqui, THN.) 
comprovam Montaigne e Descartes, é descrito na dramática seção final do Livro I, onde o autor afirma ter sido de tal modo assaltado pela "visão intensa" das inúmeras contradições e imperfeições da razão humana, que quer rejeitar toda crença e raciocínio, lançando ao fogo todos os seus livros e papeis. Só a natureza dissipará as nuvens de sua "melancolia e delírio filosóficos". ${ }^{8}$

$\mathrm{O}$ segundo movimento apresenta o remédio que a natureza oferece àquele a quem a constatação das inúmeras imperfeições e contradições da razão humana deixou de "cabeça quente" (heated my brain, diz o texto). A natureza relaxa o pendor da mente a essas elucubrações febris, apresentando alguma distração (some avocation) ou viva impressão aos sentidos. Surgem as ocupações conhecidas: ele janta, joga uma partida de gamão, conversa e se alegra com os amigos. ${ }^{9}$ Essas impressões e ocupações mais vivas o recolocam num curso mais saudável, onde imperam a indolência e o prazer. ${ }^{10}$ A natureza tem, portanto, uma vocação diversificante, que se poderia dizer humorista, pois faz desviar o curso das ideias sombrias e melancólicas para representações mais agradáveis. Ela diverte, isto é, leva a algo diferente, diverso, divertido. Ela tem o condão de conduzir àquilo que não por acaso, como se verá, é ao mesmo tempo central e problemático na concepção do homem em Pascal: a diversão (divertissement).

O terceiro momento é o do retorno à atividade do pensamento, a um ceticismo temperado. As diversões comuns não são capazes de satisfazer integralmente o indivíduo que sente brotar em si a aspiração filosófica. O exercício da inteligência implica, assim, a substituição da melancolia meditativa por diversões mais leves, e destas, novamente, por outras "mais sérias". Essa última troca - que se poderia caracterizar como uma aposta na filosofia - não foge, porém, à lógica diversificante que rege em geral a conduta dos indivíduos, muito frequentemente à revelia deles, e caberá mostrar que a decisão de fazer filosofia por parte daquele que escreve o seu "romance filosófico" no final do Livro I é somente mais uma dentre outras tantas diversificações possíveis, sendo sua peculiaridade a de assumir conscientemente (e explicitar aos leitores) a estratégia que a natureza emprega para fazer os indivíduos seguirem instintivamente a lei de variação de suas atividades. O ganho em obedecer a essa diversificação natural é duplo: do ponto de vista terapêutico, a conformidade com ela significa, para o senso comum, evitar investir ou apostar todas as suas fichas num único tipo de atividade; do 
ponto vista filosófico, ela impede a adesão monomaníaca a um só sistema de pensamento. Se tudo isso fizer sentido, o resultado, em termos interpretativos, consistirá em restituir à filosofia humiana alguma coerência que ela parece perder nas leituras que a tornam dualista, ao separarem ceticismo e natureza, filosofia e senso comum. Se a diversidade é constitutiva do homem, o vaivém entre o homem comum e o filósofo não passa de um reflexo dessa condição.

Com o revigoramento proporcionado pela diversão (jantar, gamão, conversa com os amigos etc.), o filósofo pode retornar às suas meditações, porque, entregando-se a seus devaneios ou a um passeio solitário à margem do rio, sua mente se encontra de novo na disposição adequada a elas. E o mesmo estado de espírito é exigido do leitor que irá segui-lo nas especulações do livro II e III do Tratado. Esse leitor terá de estar na mesma disposição favorável ou tranquila (easy disposition) que o próprio filósofo alcançou; do contrário, ele precisará seguir sua "inclinação" (inclination) e esperar a volta de sua "aplicação e bom humor". ${ }^{11}$

Aplicação e bom humor. Essas duas palavras sintetizam bem a novidade da filosofia humiana em relação aos modelos antigos: diante da impossibilidade de atingir a tranquilidade do sábio, a mente deve ser entretida em aplicações moderadas; e, em vez de uma serenidade da alma inalcançável, o que se deve buscar é o bom humor. O ideal do sábio estoico é inatingível, já que não se pode pautar a conduta inteiramente pela razão, e o máximo de sabedoria consistirá em trocar paixões violentas por paixões amenas ou calmas - que, ainda assim, seguirão sendo paixões.

O papel decisivo que a "ciência da natureza humana" de Hume atribui às paixões e ocupações dá bem a medida de seu distanciamento em relação às seitas filosóficas do passado e de sua maior proximidade com as filosofias de pensadores que lhe são temporalmente mais próximos. Nesse sentido, é patente a afinidade de sua concepção antropológica com ideias de Malebranche e de Locke, por exemplo, cujas indagações acerca das paixões e atividades humanas são tão bem caracterizadas por aquilo que Jean Deprun chama de "filosofia da inquietude". Quais seriam as marcas fundamentais comuns da inquiétude de Malebranche e da uneasiness de Locke (embora os dois conceitos não sejam inteiramente intercambiáveis)? Segundo Deprun, o que caracteriza estas e outras filosofias do século XVII e XVIII é o seu esforço em mostrar, em contraposição à analítica do tédio de Pascal, que a inquietação é traço

11 THN, I, IV, 7, p. 273: "If the reader finds himself in the same easy disposition, let him follow me in my future speculations. If not, let him follow his inclination, and wait the returns of application and good humour." Trad. cit., p. 305. 
essencial da natureza humana, e que toda e qualquer agitação ou ocupação da alma, remédio à letargia e inação, é benéfica ao indivíduo. $\mathrm{O}$ primeiro princípio norteador dessa antropologia foi assim explicado pelo Abbé Dubos:

A alma tem suas necessidades, como o corpo, e uma das maiores necessidades do homem é ter o espírito ocupado. O tédio [énnui] que segue rapidamente a inação da alma é um mal tão doloroso para o homem, que ele frequentemente empreende os trabalhos mais penosos a fim de evitar a pena de ser atormentado por ele. ${ }^{12}$

O homem faz de tudo para se manter ocupado, a fim de evitar o tédio. Esse primeiro princípio é chamado de "princípio de ocupação" por Deprun, que mostra que esse "horror à inação, à letargia, ao vazio, é um dos temas dominantes da sensibilidade francesa do século XVIII". ${ }^{13}$ Já a segunda regra da filosofia da inquietude é por ele chamada de "princípio de otimização". De acordo com ela, a ocupação, além de certa intensidade, causará mais pesar do que prazer. ${ }^{14}$ Como o primeiro princípio, essa regra também é fundamental para a antropologia humiana, conforme se pode verificar especialmente pelo modo como se posicionou em relação à discussão do luxo no século XVIII. Por mais sensual que seja, diz Hume, nenhum prazer pode ser considerado vicioso nele mesmo. O luxo em excesso (demasiada preocupação com os requintes culinários, por exemplo) pode indicar embotamento para outros prazeres e é sinal de falta de temperamento ou gênio, mas a satisfação que proporciona só é viciosa se vier a consumir todo o ganho do indivíduo que sucumbiu a ela, não lhe deixando "capacidade para aqueles atos de dever e generosidade requeridos por sua posição e fortuna". ${ }^{15} \mathrm{Em}$ seu comentário a respeito da "querela do luxo", Luiz Roberto Monzani assinala que aquilo que Hume denomina "luxo vicioso" parecer ser "o que entendemos por monomania ou ideia fixa", e a imagem que mais prontamente ocorre dela seria a de um jogador cuja paixão foi levada a tal ponto que absorve toda sua vida e drena todos os seus bens. A comparação é absolutamente feliz, e este texto se limitará, em grande medida, a desenvolvê-la. Diferentemente daqueles que censuram o luxo, Hume não o considera "o pior dos males da sociedade política"; a satisfação só pode ser viciosa se monopolizar todos os ganhos e todas as despesas de um indivíduo. ${ }^{16}$

12 Du Bos, J.-B. Réflexions critiques sur la poésie et sur la peinture. Paris: École Nationale Supérieure des Beaux-Arts, 1993, p. 2-3. Cf. Hume, D. "Da Tragédia”, trad. cit., p. 163-164.

13 Deprun, J. La philosophie de l'inquiétude en France au XVIIle siècle. Paris: Vrin, 1979, p. 71.

14 Idem, p. 72-73.

15 Hume, D. "Do Refinamento das Artes". O ensaio foi primeiramente chamado "Do Luxo" In: A Arte de Escrever Ensaio, p. 209 e 218.

16 Monzani, L. R. Desejo e Prazer na Idade Moderna. Campinas: Editora da Unicamp, 1995, p. 40-41. 
Uma vez de acordo que deve obedecer também a esse princípio natural da otimização, o filósofo não poderá se entregar com excesso à sua inclinação principal. Especular deve ser então uma atividade entre outras, uma "curiosidade inocente", que leva àqueles "poucos prazeres seguros e inofensivos conferidos à raça humana". ${ }^{17} \mathrm{~A}$ descoberta da verdade e o afastamento da obscuridade deleitam a mente, mas só são corretamente praticados se bem temperados por outros afazeres. É a boa distribuição das ocupações que caracteriza a condição ideal do temperamento e do humor para Hume, e isso está bem longe de um elogio da "quietude". A centralidade do princípio de otimização para a ciência da natureza humana aparece numa passagem decisiva da Investigação sobre o Entendimento Humano, que fala do "modo de vida misto" que a natureza secretamente estipulou para os seres humanos. Fundamental para o entendimento da filosofia humiana, essa passagem merece ser citada mais uma vez na íntegra:

O homem é um ser racional e, como tal, recebe da ciência seu adequado alimento e nutrição. Tão estreitos, porém, são os limites do entendimento humano que pouca satisfação pode ser esperada nesse particular, tanto no tocante à extensão quanto à confiabilidade de suas aquisições. Além de ser racional, o homem é também um ser sociável, mas tampouco pode desfrutar sempre de uma companhia agradável e divertida, ou continuar a sentir por ela a necessária atração. O homem também é um ser ativo, e é forçado, por essa inclinação e pelas variadas necessidades da vida humana, a dedicar-se aos negócios e ofícios; mas a mente exige algum descanso e não pode corresponder sempre à sua tendência ao trabalho e à diligência. Parece então que a natureza estipulou uma espécie mista de vida, como a mais adequada aos seres humanos, e secretamente os advertiu a não permitir que nenhuma dessas inclinações se imponha excessivamente, a ponto de incapacitá-los para outras ocupações e entretenimentos. ${ }^{18}$

An vivere tanti est?

Anônimo

Por que alguém decide começar a filosofar? Como quer que possa se responder a essa questão, uma coisa pelo menos é certa para Hume:

17 HUME, D. Enquiry concerning Human Understanding. Edição de Selby-Bigge, revisão de P. H. Nidditch. Oxford: Clarendon Press, 1992, p. 11. Tradução de José Oscar de Almeida Marques, São Paulo: Editora da Unesp, 2003, p. 25-26.

18 Idem, p. 6, trad. cit., p. 23. 
ninguém decide se dedicar à filosofia porque foi levado a isso unicamente por sua razão. Observação semelhante vale para a aceitação de um sistema filosófico, por exemplo, o ceticismo. $\mathrm{O}$ único efeito do ceticismo, afirma ele a propósito do ceticismo de Berkeley, é "causar perplexidade, indecisão e embaraço momentâneos". Os argumentos céticos "não admitem resposta e não produzem convicção". ${ }^{19}$ Ninguém filosofa ou aceita uma filosofia porque foi racionalmente convencido a fazê-lo. A decisão de filosofar pode aparentar ser uma das decisões mais sérias tomadas por uns poucos homens, mas ela em nada difere das demais escolhas, pois está ligada a uma promessa de prazer similar àquele que se espera obter noutras ocupações. Mas não parece um tanto gratuito conceber assim a filosofia como "mais uma" entre as atividades humanas, comparando-a às demais diversões? Essa gratuidade é, sem dúvida, aparente, pois a continuidade entre natureza e filosofia parece pedir para ser explicada exatamente a partir daqui: a compreensão do valor que se confere às ocupações sérias, aos passatempos, à filosofia, não pode ser desvinculada da compreensão da importância que se dá à vida.

Qual a medida correta para a conduta da vida, e essa medida não seria também idêntica para a filosofia? A mesma pergunta poderá ser feita de outra maneira: até que ponto se deve levar a sério um jogo que, como todo jogo, para ser bem jogado, não pode ser levado a sério demais? É para esse difícil equilíbrio entre seriedade e jogo que Hume chama atenção quando escreve:

A vida humana é, numa palavra, mais governada pela sorte do que pela razão; deve ser considerada mais um passatempo tolo do que uma ocupação séria, e é mais influenciada pelo humor particular do que por princípios gerais. ${ }^{20}$

A vida se assemelha mais a um jogo de azar do que a um ofício grave e solene. Antes que se acuse o autor de frivolidade, é preciso entender bem o sentido dessa comparação da vida com um dull pastime, porque ela serve para rejeitar ao menos duas ideias igualmente desastrosas: a de que a vida humana tem um valor infinito e a de que ela não tem valor nenhum.

A primeira concepção, de que a vida humana tem um valor intrínseco altíssimo, é a concepção da superstição e da falsa religião, que Hume combate ponto por ponto no ensaio sobre o suicídio:

19 Idem, p. 155, trad. cit., p. 210.

20 Hume, D. "O Cético". Trad. cit., p. 145. A frase toda merece ser citada no original: "In a word, human life is more governed by fortune than by reason; is to be regarded more as a dull pastime than as a serious occupation; and is more influenced by particular humour, than by general principles." 
Porque a vida humana é tão importante, seria presunção da prudência humana abdicar dela? A vida do homem, no entanto, não tem mais importância para o universo do que a de uma ostra. E, qualquer que possa ser a sua importância, o que ocorre na realidade é que a ordem da natureza a submeteu à prudência humana, levando-nos à necessidade de tomar, a cada incidente, uma decisão a respeito dela. ${ }^{21}$

The life of men is of no greater importance to the universe than that of an oyster. É a ordem natural que ensina a verdadeira dimensão da vida, dizendo que o escrutínio sobre sua importância deve ficar a cargo do temperamento particular e da prudência de cada um, para que a examine a cada ocorrência, não devendo se pautar por regras ou preceitos gerais. Mas esse exame só é bem sucedido se a prudência humana respeita, em cada caso, aquilo que parece ser ditado pela ordenação natural, o que, por sua vez, será estampado no humor de cada um.

A outra concepção que Hume pretende refutar é a de que a vida não tem valor algum. A vida humana é mais um passatempo estúpido que um empreendimento sério. É como passatempo, no entanto, que ela pode adquirir algum valor, e adotar essa posição serve de antídoto a duas doxas "extraídas da vida comum" e encontradas com bastante frequência nos "livros de filosofia". A primeira dessas doxas afirma que, diante da brevidade e incerteza da vida, toda busca por felicidade parece desprezível. A segunda assevera que "os projetos mais amplos e generosos" serão frívolos e inúteis se comparados às "incessantes mudanças e revoluções dos assuntos humanos", que reduzem por fim a nada todos os esforços mais benevolentes e os empreendimentos mais ousados dos homens. O problema do raciocínio que subjaz a tais considerações está em que estas, se ganham força de convicção e viram regra de conduta, se tornam contraditórias, pois provocam o arrefecimento daquilo que motiva a vida, levando à inação, o que significaria justamente agir contra a natureza. É o questionamento que se faz o ensaio sobre o cético:

Tal reflexão certamente tende a arrefecer todas as nossas paixões; mas com isso ela não operaria na direção contrária à do artifício pelo qual a natureza logrou nos induzir à opinião de que a vida humana tem alguma importância? ${ }^{22}$

Mais uma vez, o texto é contundente: Nature has happely deceived us into an opinion that human life is of some importance. Transformadas em reflexão filosófica, as máximas da vida comum que acabam por frequentar as páginas 
dos livros de filosofia agem exatamente na direção contrária (conterwork) a esse estranho ardil pelo qual a natureza consegue implantar nos homens a ilusão salutar de que as suas vidas têm "alguma importância". Ora, como se vê, toda a dificuldade de Hume estará em explicar como a natureza se transforma em arte, isto é, como ela prepara esse artificio (artifice) graças ao qual os homens têm a impressão de que a vida é "of some importance". Mas Hume terá de explicar também, o que não é menos difícil, como se mede essa alguma importância.

Parece óbvio pensar que a teoria das ideias e da vivacidade das impressões seja o ponto de partida dessa aferição. De acordo com ela, todo objeto dos sentidos ou imagem da fantasia tem ligação com o sentimento ou emoção, mesmo que essa ligação já não seja notada. Como diz Hume:

Creio que se pode estabelecer seguramente, como máxima geral, que todo objeto que se apresenta aos sentidos e toda imagem que se forma na fantasia são acompanhados de alguma emoção ou movimento proporcional dos espíritos animais; e por mais que o costume nos torne insensíveis a essa sensação, e nos faça confundi-la com o objeto ou com a ideia, será fácil separá-los e distingui-los por meio de experimentos cuidadosos e precisos. ${ }^{23}$

Há no Tratado outro texto no qual se explica essa agitação dos sentimentos e dos espíritos animais, e no qual se pode perceber uma clara tomada de posição em relação às análises do tédio desenvolvidas por Pascal:

Aqueles que se comprazem em lançar invectivas contra a natureza humana observaram que o homem é inteiramente incapaz de se bastar a si mesmo, e que, se desfizermos todos os laços que mantém com os objetos externos, ele imediatamente mergulhará na mais profunda melancolia e desespero. É por isso, dizem eles, que estamos continuamente à procura de diversão, seja no jogo, na caça, ou nos negócios; por meio dessas atividades, tentamos nos esquecer de nós mesmos e resgatar nossos espíritos animais daquele torpor em que caem quando não são mantidos por alguma emoção enérgica e vivaz. ${ }^{24}$

Hume afirma que só pode concordar com esse "método de pensamento" (method of thinking) dos que declamam contra a natureza humana, porque reconhece que a mente é por si só insuficiente para seu próprio entretenimento (to its own entertainment) e que, por isso, ela busca outros objetos como jogo, caça ou negócios, que "possam produzir viva sensação e agitar os espíritos 
animais". ${ }^{25}$ Como lembra Dubos, é preciso admitir que são poucas as pessoas felizes a ponto de não sentirem desconforto quando se veem abandonadas a si mesmas; são raras as que conseguem ser "boas companhias" para si próprias, e somente um pequeno número pode aprender a arte horaciana de travar amizade consigo mesmo (quod te tibi reddat amicum) ${ }^{26}$ Mas, é claro, tanto Dubos como Hume só aceitam as constatações de Pascal sobre o mal-estar de restar a sós com o próprio pensamento para lhes inverter o sinal. Não é apenas o indivíduo que é infeliz sozinho; a sociedade também é naturalmente agradável porque apresenta objetos da maior vivacidade, isto é, seres racionais e pensantes que comunicam seus sentimentos e afetos mais íntimos, deixando ver, no momento em que surgem, as emoções causadas pelos mais diferentes assuntos. Privar os homens desse prazer seria lhes retirar a vantagem de experimentar paixões de pessoas mais ou menos próximas com o distanciamento que as torna menos perturbadoras, pois em sociedade elas são vividas como ideias de reflexão que podem se converter numa "espécie de paixão". Uma paixão certamente um pouco mais fraca do que aquela de quem a sentiu diretamente, embora forte o bastante para agitar agradável e beneficamente o ânimo daquele a quem é comunicada, e que é por ela comovido mediante simpatia. ${ }^{27}$

...o espírito humano se revela melhor no jogo que nas questões mais sérias.

Leibniz, Novos Ensaios, IV, xvi, § 9

Mas o que explica os aspectos quantitativos do prazer e da dor numa impressão ou ideia, e como eles se convertem em aspectos qualitativos, isto é, como uma impressão ou sentimento pode se converter num "valor"?

A explicação que o Tratado apresenta para a "quantificação" do prazer beira o simplismo: qualquer objeto muito grande (o oceano, uma planície extensa, uma cadeia de montanhas etc.) ou qualquer coleção muito numerosa (um exército ou uma multidão) provocam sensível emoção na mente, "um prazer dos mais intensos que a natureza humana é capaz de experimentar", 
efeito composto da conjunção dos diversos elementos de que consiste a sensação. A conclusão é óbvia:

Portanto, cada parte da extensão, bem como cada unidade numérica, quando concebida pela mente, vem acompanhada de uma emoção separada. Essa emoção nem sempre é agradável; entretanto, por sua conjunção com outras, e porque agita os espíritos animais no grau adequado, contribui para produzir a admiração, que é sempre agradável. ${ }^{28}$

Como não há ideia que não corresponda a uma impressão, há um atomismo não apenas na teoria das ideias, mas também na teoria do prazer e dor. Seguindo Locke, para quem prazer e dor (mas principalmente esta) são os princípios da ação, Hume afirma:

O principal motor ou princípio de ação da mente humana é o prazer e a dor; e quando essas sensações são retiradas de nosso pensamento e sentimento, ficamos, em grande medida, incapazes de paixão ou ação, de desejo ou volição. ${ }^{29}$

Aquele of some importance que dava o índice de valor da vida parece poder ser medido nesses termos quantitativos, uma vez que não só as impressões e ideias simples, mas também as mais complexas estão ligadas ao prazer que contêm. A importância que se dá à vida seria, assim, diretamente proporcional à quantidade de sensações boas que se adquire. Ou seja, deve haver um mínimo de prazer (superior à quantidade de dor) aquém do qual a saída mais razoável é o suicídio: abaixo dele, a vida perderia o sentido, isto é, não mereceria ser vivida. Acima desse mínimo, a importância aumentaria em graus. Há um texto elucidativo a esse respeito na seção sobre a probabilidade das causas do Tratado. A passagem que interessa trata da diferença entre dez mil chances de um lado e dez mil e uma de outro. Por que o juízo escolhe dez mil e uma chances de que algo ocorra e não dez mil, embora a diferença seja mínima e impossível de identificar a vivacidade superior de umas sobre as outras? Sem responder diretamente a questão, o texto diz que a solução desse problema de probabilidade é análoga ao que ocorre na afetividade:

Temos um exemplo análogo no caso dos afetos. De acordo com os princípios acima mencionados, é evidente que, quando um objeto produz em nós uma paixão que varia conforme as diferentes quantidades do objeto, a paixão não é, propriamente falando, uma emoção simples, mas composta de um grande número de paixões mais fracas, derivadas da visão de cada parte do objeto. 
Por essa explicação, um homem que deseja possuir mil libras "tem na realidade mil ou mais desejos que, ao se unirem, parecem formar uma paixão só." Mas, se a paixão parece ser uma só, o que explica que o indivíduo prefira uma quantidade maior a uma menor, mesmo quando a diferença é imperceptível (dez mil e uma chances contra dez mil)? A preferência pelo número maior, por ínfima que seja a diferença, não se deve à paixão, mas ao "hábito e a regras gerais" que assim se explicam:

Mediante uma multiplicidade de exemplos, descobrimos que, quando os números são precisos e a diferença sensível, o aumento do montante de uma quantia qualquer de dinheiro aumenta a paixão. A mente é capaz de perceber, por sentimento imediato, que três guinéus produzem uma paixão maior que dois; isso ela transfere para números maiores, em razão da semelhança; e, por uma regra geral, confere a mil guinéus uma paixão mais forte que aquela que confere a novecentos e noventa e nove. ${ }^{30}$

Do ponto de vista estritamente quantitativo, o que se pode obter com mil guinéus não é muito diferente do que aquilo que se compra com novecentos e noventa e nove. A diferença é irrisória e só se torna significativa, porque a mente transfere, por semelhança, para quantias maiores o que sentiu em experiências anteriores com números menores e mais nítidos. O que conta, no entanto, é que as unidades não aparecem isoladas, mas formando uma paixão só, que "supera" a expectativa de prazer dada por uma quantidade pouco menor. Como no caso da conexão de causa e efeito, o costume opera sobre a imaginação produzindo, ali uma crença, aqui uma paixão.

A repetição quantitativa da experiência, embora importante, talvez não dê inteiramente conta do modo como a natureza ensina os homens a valorizar a vida. Uma explicação mais consistente e completa parece depender da compreensão do papel essencial desempenhado pela inventividade das paixões no interior da filosofia humiana. ${ }^{31} \mathrm{Na}$ natureza humana, a invenção é ativada sempre que a mente se vê diante de uma dificuldade: toda vez que observa uma contradição, irregularidade, inconstância ou exceção, a mente tenderá a buscar uma solução, num procedimento análogo àquele em que procura evitar alguma perturbação ou desconforto, como o tédio. Por exemplo, na controvérsia sobre a continuidade da existência dos objetos externos (negada pelo cético, afirmada pelo senso comum), o incômodo que a mente sente a impele a encontrar uma solução conciliatória:

30 THN, I, III, 12, p. 141; trad. cit., pp. 174-175.

31 O papel da invenção na constituição da natureza humana foi devidamente assinalado por Gilles Deleuze em seu Empirisme et subjectivité. Essai sur la nature humaine selon Hume, Paris: PUF, $3^{a}$ ed., 1980, ainda que o tenha restringido ao âmbito da sociedade e da cultura. 
Para eliminar nosso desconforto acerca desse ponto, fabricamos [we contrive] uma nova hipótese, que parece compreender ambos os princípios, o da razão e o da imaginação. Trata-se da hipótese filosófica da dupla existência, das percepções e dos objetos, que satisfaz nossa razão, ao admitir que nossas percepções dependentes são descontínuas e diferentes; e, ao mesmo tempo, é agradável para a imaginação, por atribuir uma existência contínua a outra coisa, a que chamamos objetos.... Incapazes de reconciliar essas duas inimigas [natureza e razão], procuramos tanto quanto possível amenizar nosso desconforto [to set ourselves at ease], dando sucessivamente a cada uma aquilo que ela pede, e criando a ficção de uma dupla existência... ${ }^{32}$

Noutra passagem, explicando a origem das ideias de justiça e propriedade, o Tratado afirma que a parcialidade das afecções pode ser corrigida por um remédio que não se deve à natureza, mas a um artificio. A palavra em inglês é a mesma que foi usada mais tarde no ensaio sobre o cético - artifice -, mas como se quisesse evitar a solução pelo artifício, o texto se emenda incontinente dizendo: "ou, falando mais propriamente, a natureza providencia, nojulgamento e entendimento, um remédio para aquilo que é irregular e incômodo nas afecções". ${ }^{33}$ Tudo aquilo que desajusta o equilíbrio e a regularidade é sentido como incômodo, e a mente busca naturalmente um artificio para remediá-lo. Esse processo inventivo depende sobretudo das paixões: "Nada é mais atento e inventivo que as nossas paixões" 34 , sempre vigilantes e criativas diante do que possa vir a incomodar, e se podem se tornar geradoras de artificialidade - do rigor da sociedade e das normas culturais -, é porque as regras artificiais, embora em parte as restrinjam, são o meio mais seguro e cômodo de continuar evitando o desconforto e gerando novas satisfações.

A curiosidade cativa o sábio; a vaidade, o tolo; o prazer, a ambos.

David Hume ${ }^{35}$

Seria preciso tentar explicar como funciona essa inventividade própria das paixões, pois, caso se consiga tornar claro o seu mecanismo, ele ajudará a compreender melhor como a natureza ensina esse artifício pelo qual se dá valor ou "algum valor" à vida. 
No ensaio sobre o cético há indicações que podem levar a uma resposta mais precisa sobre esse ponto. A natureza ensina que a vida, tendo alguma importância, deve ser considerada mesmo assim mais um passatempo do que uma ocupação séria:

A vida é como um jogo: pode-se escolher o jogo, e a paixão gradualmente se apodera do objeto adequado. ${ }^{36}$

Life is like a game: se as ocupações, como o jogo, são indispensáveis à mente, é a paixão que torna a ocupação ou jogo escolhido uma atividade propriamente interessante, porque o indivíduo vai aos poucos se afeiçoando a ela e se apoderando de um objeto que lhe causa sempre mais satisfação. A leitura da seção 10, parte III, livro II do Tratado, pode ajudar no entendimento dessa relação complexa entre vida, jogo e paixão. Mais ainda, por tratar da "curiosidade, ou o amor à verdade", essa última seção do Tratado ajuda também a entender essa paixão muito particular que está na raiz da inclinação para a filosofia e da tomada de decisão por ela, já que, como afirma o autor, de um ponto de vista retrospectivo todas as discussões feitas ao longo da obra supunham a curiosidade, que era "a primeira fonte de todas as nossas investigações". ${ }^{37}$ Há assim, entre vida, jogo e essa afecção peculiar que está na base da filosofia uma ligação que merece ser estudada mais de perto.

A argumentação que tenta explicar essa "curiosidade inocente" 38 também chamada "amor à verdade" se inicia afirmando que, das duas espécies de verdade existentes, a que diz respeito à relação entre ideias é mais interessante do que a atinente às questões de fato para revelar o modo de proceder dessa paixão. Isso porque, no caso da descoberta de verdades geométricas, a mente se limita a dar assentimento às conclusões justas, e, na resolução de questões algébricas, as operações não são acompanhadas de quase nenhum prazer, se é que não são seguidas de dor. Noutras palavras, é justamente a ausência de prazer nas relações de ideias que revela algo essencial, pois é "prova evidente de que a satisfação que algumas vezes obtemos com a descoberta da verdade não procede desta [verdade] considerada meramente enquanto tal, mas somente se dotada de certas qualidades". ${ }^{39}$

36 HUME, D. "Sobre o Cético", trad. cit., p. 143.

37 THN, II, III, 10, p. 448; trad. cit., p. 484 (grifo nosso).

38 A reflexão filosófica é uma "curiosidade inocente", "um dos poucos prazeres seguros e inofensivos concedidos à raça humana", dizia a passagem capital da Investigação sobre o Entendimento Humano citada na nota 18.

39 THN, II, III, 10, p. 448-449; trad. cit., p. 484. 
O exemplo das matemáticas mostra que, para que a descoberta da verdade traga satisfação, não basta que a verdade descoberta seja apenas "certa e justa", mas que também seja acompanhada de certas propriedades. E a primeira condição indispensável para tornar a verdade prazerosa é o "gênio e capacidade empregados na sua descoberta". O que é fácil e óbvio "nunca é valorizado", e até aquilo que é difícil em si mesmo recebe pouca consideração se é alcançado "sem dificuldade e sem um extremo esforço do pensamento ou juízo". Entretanto, embora seja a fonte principal de satisfação com a ciência, o exercício do gênio ainda não é suficiente para proporcionar "algum contentamento considerável". Além dele, é preciso mais um ingrediente:

A verdade que descobrimos também tem de ter alguma importância. ${ }^{40}$

Of some importance: não é certamente fortuito que a mesma locução surja em duas passagens capitais da obra humiana; pelo contrário, ela parece dar uma chave preciosa para compreender a continuidade entre vida e filosofia presente nessa obra. Pois, se nos Ensaios é a natureza que ensina que a vida tem lá sua importância, de maneira análoga, no Tratado, a atividade do pensamento só dá satisfação quando busca e descobre verdades que sejam de alguma relevância. $\mathrm{O}$ intrigante é saber de que maneira essa certa utilidade e importância das verdades científicas age sobre aqueles que, abrindo mão de recompensas talvez mais imediatas, se entregam a sua descoberta. Por que filósofos que não manifestam o menor interesse público, nem estima pela humanidade, acabam por consumir seu tempo, destruir sua saúde e desprezar riquezas em busca de verdades que consideram "importantes e úteis para o mundo"? Por que, apesar da sua falta de civismo e de humanidade, eles perderiam todo o gosto pelos estudos, se percebessem que suas descobertas eram of no consequence? ${ }^{41}$ Aqui como em tantos outros tópicos, a conjunção entre as ideias está longe de ser explicada de modo estritamente racional.

Na sequência do texto da última seção do livro sobre as paixões, os pontos da argumentação são retomados e explicitados. O prazer do estudo consiste no exercício do gênio e do entendimento, mas não só: para que ele se complete é preciso que a verdade seja importante, não porque a importância acrescente algo à satisfação, mas porque ela é necessária em alguma medida para... fixar a atenção. ${ }^{42} \mathrm{E}$ resta ainda outro aspecto. Além da ação da mente 
e da certa relevância do objeto de estudo, há ainda uma observação de caráter geral a ser feita: toda busca tem de ser coroada de algum êxito. Quando a mente busca com paixão algum objetivo, no final esse objetivo mesmo passa a ter interesse, ainda que de início ou até em si mesmo ele fosse completamente desinteressante e irrisório. Por isso, por paradoxal que pareça, pode-se dizer que o fim é um fim qualquer, que não está propriamente conectado com a paixão, e somente o mecanismo afetivo permite fazer a ligação entre essas ideias inicialmente desconexas - a paixão e seu objeto! O procedimento é análogo ao que conecta o efeito à causa nas questões de fato. Isto é, se os afetos seguem seu curso natural, com algum êxito na busca será estabelecido um elo entre o fim e a paixão que não existia antes, e a partir daí se sentirá "desconforto" (uneasy) se a busca fracassa. ${ }^{43}$

Esse dispositivo que explica a curiosidade ou o amor pela verdade é elucidado mediante dois exemplos ou, mais precisamente, mediante duas comparações: o exercício filosófico pode ser comparado à caça e ao jogo. Por mais que à primeira vista pareçam diferir uma da outra, não há, observa Hume, "duas paixões mais proximamente similares uma à outra que as da caça e da filosofia". Na caça, o prazer consiste "na ação da mente e do corpo; no movimento, na atenção, na dificuldade e na incerteza". Essas ações e agitação da mente e do corpo precisam ser acompanhadas de alguma ideia de utilidade: o homem de grande fortuna e sem nenhum traço de avareza tem prazer em caçar perdizes e faisões, mas não corvos e gralhas, porque aqueles são próprios para a mesa, e estes totalmente inaproveitáveis (useless). Essa utilidade ou importância (utility or importance) não provocam nenhuma paixão real (o homem dado como exemplo é rico e nem um pouco avaro), mas são requeridas apenas para... dar sustento à imaginação (exatamente como, há pouco, a relevância da verdade era necessária tão-somente para fixar a atenção). Contudo, é fácil pensar que haja alguém capaz de trocar algo mais proveitoso pelo prazer de trazer para casa meia dúzia de galinholas, depois de ter gasto horas a caçá-las. Embora em ambos os casos, isto é, na caça e na filosofia, seja possível desprezar o fim a que se propõem as ações, "concentramo-nos tanto nele, no calor dessa ação, que nos sentimos muito mal quando desapontados, e ficamos tristes se perdemos nossa presa ou se cometemos um erro em nosso raciocínio". ${ }^{4}$

Essa comparação de coisas aparentemente tão díspares como filosofia e caça não é propriamente da lavra de Hume, pois ela retoma a ideia de investigação formulada por Montaigne e reafirmada por Locke. Para 
Montaigne, mais importante que o assunto é a "maneira" com que ele é tratado. A "agitação" e a "caça" estão no centro do interesse dos homens, e eles têm de agir da maneira como convém a elas. Isto é, não importa se consigam ou não capturar a presa que buscam, pois o essencial é busca, uma vez que eles são nascidos "para investigar a verdade (nous sommes nés pour quêter la vérité)". Já possuir a verdade requer uma potência muito superior. ${ }^{45} \mathrm{~A}$ ideia de que é a investigação o que define a atividade filosófica, independentemente do seu resultado, reaparece na "Epístola ao Leitor", que abre o Ensaio sobre o Entendimento Humano de Locke:

Aquele que caça cotovias e pardais, embora estas sejam presas bem menos consideráveis, não tem menos divertimento [sport] que aquele que se lança num jogo mais nobre; e tem pouca familiaridade com o assunto deste tratado - o entendimento - quem não sabe que, sendo a faculdade mais elevada da alma, ele é empregado com deleite maior e mais constante do que todas as outras. Suas buscas pela verdade são daquela espécie de caça e perseguição [hawking and hunting] na qual é a própria busca que dá grande parte do prazer. ${ }^{46}$

Se para Montaigne e Locke o que importa na investigação ou ensaio é menos o objetivo a ser alcançado, a presa que se captura, do que a busca, o inquérito, a inquisição - "Le monde n'est qu'une école d'inquisition”, diz Montaigne $^{47}$-, a contribuição de Hume, ao fazer coro com esses dois autores, reside na tentativa de explicar como, do ponto de vista da teoria das paixões, a atividade pode ser mais importante que o fim, ou até como é ela que torna o fim realmente desejável. A escolha de uma atividade (não só da filosofia) depende de cada um. E o prazer e a frustração que a acompanham são proporcionais à paixão com que o homem nela se empenha. É o que lembra o ensaio sobre o "Padrão do Gosto":

Já observamos que nenhum objeto é desejável ou detestável, valoroso ou desprezível em si mesmo, mas adquire essas qualidades no caráter e constituição particulares da mente que os considera. Não há, portanto, argumentos ou razões diretas que possam ser utilizados com alguma força ou influência para diminuir ou aumentar o apreço que uma pessoa tem por um objeto, para excitar ou moderar suas paixões. Se a Domiciano dá mais prazer capturar moscas, então isso lhe é preferível a caçar feras selvagens, como Guilherme Rufo, ou a conquistar reinos, como Alexandre. ${ }^{48}$

45 Montaigne, M. "De l'art de conférer" in Essais, III, VIII. Texto estabelecido, apresentado e anotado por Pierre Michel. Paris: Gallimard, 1973, p. 191-192.

46 LOCKE, J. An Essay concerning Human Understanding. In: The Works of John Locke. Londres: Routledge/ Thoemmes Press, 1997, vol. 1, p. 4.

47 Montaigne, M., op. cit., p. 192.

48 "O Cético", trad. cit., p. 137. 
O apreço por um objeto depende da constituição individual, e raciocínio algum fará aumentar ou diminuir diretamente esse apreço. Todas essas constatações levam a uma curiosa conclusão acerca da conduta humana em Hume, isto é, acerca dos cálculos que o homem faz em sua vida. Voltando ao exemplo dos mil guinéus, ali se poderia imaginar que a natureza humana é calculista: ela sabe, por experiência e hábito, que mil prazeres representam mais que novecentos e noventa e nove. Mas o que se percebe também é que a paixão sabe inventar um valor que não é necessariamente detectável em termos frios e objetivos. As coisas não podem ser tomadas em valores absolutos. Essa ideia é devidamente explicada no ensaio sobre o "Cético". Diz o texto:

De tudo isso se infere que não é pelo valor ou serventia do objeto buscado que podemos determinar o contentamento de uma pessoa, mas meramente pela paixão com que ela o busca e pelo sucesso de sua busca. Os objetos não têm em si mesmos absolutamente nenhuma serventia ou valor. Eles tiram seu valor meramente da paixão. Se esta é poderosa, estável e afortunada, a pessoa é feliz. Não é razoável duvidar que o contentamento de uma jovem trajando um vestido novo para o baile da escola seja tão completo quanto o do maior orador que, triunfante no esplendor de sua eloquência, governa as paixões e resoluções de uma assembleia numerosa. ${ }^{49}$

Assim como na diferença de objetos de desejo entre Domiciano, Guilherme Rufo e Alexandre, aqui também o fascínio da jovem pelo seu vestido não é menor do que o apreço do orador pela sua eloquência. A paixão com que se busca, mas também a repetição, a constância e o êxito na busca são os fatores determinantes do valor de um objeto. Entretanto, além da comparação com a caça, o mecanismo atuante na curiosidade ou busca da verdade também pode ser explicado por comparação com a paixão pelo jogo [passion of gaming], e nesta se evidencia ainda mais claramente a proximidade de Hume com a discussão do divertimento em Pascal e com a contra-argumentação por parte de Dubos. Os elementos que ele descreve o prazer pelo jogo retomam vários pontos desses dois autores. O interesse por uma atividade tem primeiro de fixar nossa atenção:

O interesse que temos por um jogo atrai nossa atenção, sem o que não teríamos nenhum prazer, nessa ou em qualquer outra ação.

Depois de fixada a atenção, surgem outras agitações que, embora mescladas a dor ou desprazer, servem para o objetivo principal, que é aliviar o enfado: 
Uma vez atraída a atenção, a dificuldade, a variedade e os súbitos revezes da sorte fazem que nos interessemos ainda mais; e é desse interesse que resulta nossa satisfação. A vida humana é uma cena tão enfadonha, e os homens em geral são tão indolentes, que tudo que os diverte, ainda que por uma paixão mesclada de dor, no essencial lhes dá um prazer perceptível. Esse prazer aumenta ainda mais, neste caso, pela natureza dos objetos, que, sendo sensíveis e de âmbito limitado, são concebidos com facilidade e agradam a imaginação. ${ }^{50}$

É de notar, além disso, que os ingredientes essenciais que compõem o prazer do jogo são os mesmos que entram na composição da satisfação com a caça e com a filosofia. Nesses três casos, o prazer advém da combinação de interesse e desinteresse:

Observou-se que o prazer do jogo não decorre apenas do interesse, pois muitos abrem mão de um ganho certo por essa diversão. Tampouco deriva apenas do jogo, pois essas mesmas pessoas não sentem nenhuma satisfação quando não jogam por dinheiro. Procede antes da união dessas duas causas, embora, sozinhas, elas não tenham nenhum efeito. Ocorre aqui o mesmo que em certos preparados químicos, em que a mistura de dois líquidos incolores e transparentes produz um terceiro que é opaco e colorido. ${ }^{51}$

Esses trechos mostram o quanto a argumentação humiana parece seguir conscientemente, item por item, os pensamentos de Pascal. O que está em questão nas diversões não é a prenda que se ganha, mas a agitação da alma: assim como o que importa na caça não é a presa, mas a caçada, assim também o que interessa no jogo é ocupar a alma, porque, como diz Pascal, é a "ocupação violenta e impetuosa que desvia [os homens] de pensar em si mesmos". ${ }^{52}$ Um homem passa a vida "sem tédio" arriscando todo dia uma pequena soma no jogo. Se lhe derem toda manhã o dinheiro que ganharia jogando, sob a condição de não jogar, ele ficará infeliz. Poder-se-ia argumentar que o prazer está no jogo, não no ganho; mas se ele não jogar por nada, "não se animará e se entediará". Entretanto, "é preciso que ele se anime e se engane a si mesmo" imaginando o quanto ficaria feliz em ganhar aquilo que lhe querem dar de mão beijada, caso renuncie a jogar. O jogador não joga pelo dinheiro que ganhará, mas sem a ilusão de ganhar alguma coisa, ele não se "forma um objeto de paixão" que lhe excite o desejo, a cólera, o receio em relação ao objeto mesmo que ele se formou, "como as crianças que se assustam com o rosto que elas

50 THN, II, III, 10, p. 452; trad., p. 488. Cf. Dubos, p. 8.

51 THN, II, III, 10, p. 452; trad., pp. 487-488.

52 PASCAL, B. Pensées, 126. In: Oeuvres Complètes. Edição de M. Le Guern. Paris: Gallimard, 2000, vol. 2, p. 585. Esse pensamento sobre o divertissement corresponde ao de número 117 da edição de Lafuma. 
mesmas traçaram". ${ }^{53}$ Pelo que se viu antes, Hume está plenamente de acordo: é a ilusão que forma um objeto de paixão (un sujet de passion), e somente este desencadeia outras paixões inerentes à atividade de jogar: a atenção, a dificuldade, a incerteza, os súbitos revezes da sorte e do azar...

Há ainda uma semelhança a salientar entre as argumentações de Pascal e Hume. Para explicar a "ilusão" que forma a paixão, Pascal não se limita a recorrer a um artifício da natureza como Hume, mas a dois instintos secretos: um deles, que leva os homens "a buscar o divertimento e a ocupação fora deles, vem do ressentimento de suas contínuas misérias"; o outro, que "resta da grandeza da nossa primeira natureza", ensina que a felicidade não se encontra no tumulto, mas no repouso. Movidos por esses dois instintos contrários, os homens se formam um "projeto confuso" que resta oculto à visão deles, no fundo de suas almas, e "que os leva a tender ao repouso pela agitação". ${ }^{54}$

No entanto, apesar da semelhança no modo como explicam a paixão pelo jogo, a diferença entre Pascal e Hume é bem significativa. Leitor de Montaigne, Pascal também concebe que o que importa na recherche de la vérité não é jamais buscar as coisas mesmas, e sim a busca das coisas. ${ }^{55} \mathrm{O}$ seu foco, porém, é outro: se não é correto dizer que a busca de diversão é intrinsecamente ruim, se o divertissement guarda um aspecto positivo, pois é pela radicalização de sua miséria que o homem entrevê sua grandeza ${ }^{56}$, esse aspecto positivo só entra em linha de conta em função de algo que lhe é exterior, e o movimento só tem significado e valor em vista da salvação ou do repouso. Para Hume, o aspecto positivo está na própria ação: à primeira vista poderia parecer que os divertimentos - jogar gamão, jantar conversar com os amigos - só ocorrem em benefício de uma atividade "superior", o exercício intelectual, a meditação filosófica. ${ }^{57}$ Mas isso não explica a relação entre filosofia e demais atividades, pois, do ponto de vista da economia das paixões, não há superioridade de uma

53 Idem, p. 586.

54 Essa tendência, de buscar o repouso através do movimento, continuará fundamental na nova antropologia da inquietude, entre aqueles que, como Malebranche, que contestam os princípios de Pascal, conforme explica Robert Mauzi no seu L'idée du bonheur dans la philosophie et la pensé français au XVIII siècle: "A felicidade está no repouso, sonho oculto no fundo de toda sabedoria; mas ela está também no movimento, necessário à vida da alma" (Paris: Armand Colin, 1969, p. 16). O fundamental parece ser que, com a nova antropologia, já não se pode voltar à noção antiga de "tranquilidade da alma".

55 PASCAL, Pensées, 647, ed. cit., p. 804. Corresponde ao pensamento 773 na ordenação de Lafuma.

56 Questões discutidas, entre outros, por L. Thirouin em L'hasard et les règles: le modèle du jeu dans la pensée de Pascal. Paris: Vrin, 1991.

57 Assim como a brincadeira ou jogo, para Aristóteles, não é um fim, mas apenas um meio, "porque não podemos trabalhar ininterruptamente"; a paidia só existe em vista da atividade (Ética Nicomaquéia, X, VI, 2-5, 1176 b20 e segs.). Uma perspectiva diferente sobre as relações da filosofia com o jogo desde da Antiguidade pode ser encontra em J. HUIZINGA, "Formas Lúdicas da Filosofia", in: Homo Ludens. O Jogo Como Elemento da Cultura. São Paulo: Perspectiva, 2007, 5a ed., trad. de João Paulo Monteiro. 
atividade sobre a outra. Escolher se dedicar à filosofia não é consequência lógica e natural de raciocínios consistentes; a decisão que leva a ela é menos resultado de uma argumentação teórica, que fruto de um cálculo prático que se aprende pela observação reiterada da natureza. Esse cálculo é entendido como um jogo. Hume pode muito bem não ter sido o iniciador da ideia de autonomia estética (jogo vivificador das faculdades da mente, como dirá Kant), mas talvez sua posição seja até mais radical, pois é a partir dele que se pode detectar mais claramente a ideia de que não só a filosofia, mas toda atividade implica sua autolegitimação, devendo ser entendida como um jogo que traz em si as regras de como deve ser jogado. Nenhum objeto tem valor intrínseco, pois o valor só lhe é conferido pela paixão que inventa as regras do jogo. E talvez se possa dizer que a peculiaridade do jogo filosófico resida em conseguir decifrar as regras dos outros jogos.

Esclarecido o mecanismo que é a fonte da curiosidade, é possível voltar ao romance filosófico da última seção do livro I do Tratado. Ali Hume apresenta ao leitor os motivos que o levaram a se dedicar à filosofia, elencando os sentimentos que contaram na sua decisão:

Não posso deixar de sentir curiosidade sobre os princípios morais do bem e do mal, a natureza e o fundamento do governo, e a causa das diversas paixões e inclinações que me movem e governam. Sinto-me desconfortável [I am uneasy] ao pensar que aprovo um objeto e desaprovo outro, que chamo alguma coisa de bela e outra de feia, que tomo decisões acerca da verdade e falsidade, da razão e da insensatez, sem saber com base em que princípios o faço. Preocupo-me com a condição do mundo erudito, envolto em uma ignorância tão deplorável acerca de todos esses pontos. Sinto crescer em mim a ambição de contribuir para a instrução da humanidade, e de conquistar um nome por minhas invenções e descobertas. Tais sentimentos brotam naturalmente em minha disposição presente; e se eu tentasse erradicá-los, dedicando-me a qualquer outra tarefa ou divertimento, sinto que perderia no âmbito do prazer; e esta é a origem de minha filosofia.

As paixões que o movem e governam, assim como o que espera ganhar tentando satisfazê-las, são decisivos para que Hume abdique de outros divertimentos pela filosofia, e ele sente que seria um perdedor no tocante ao prazer (I feel I shou'd be a loser in point of pleasure), se trocasse a mesa do jogo filosófico por qualquer outra. E, muito embora os próprios princípios que explicam a sua escolha sejam generalizáveis, Hume sabe muito bem que a explicação para a origem da sua filosofia não pode generalizada, como se a sua tomada de decisão em favor da filosofia pudesse valer para todo e qualquer indivíduo. Se ele pode recomendar a filosofia como uma ocupação adequada aos homens (mais, por exemplo, que a superstição), essa recomendação também vale para outras atividades que, como as ligadas à literatura e às artes, 
permitem trocar paixões fortes por paixões mais fracas e constantes. ${ }^{58}$ Deixar escapar essa diferença é não ver algo decisivo sobre o modo como se deve jogar em filosofia.

Com boa dose de tranquilidade e otimismo em relação aos princípios que governam a natureza humana, Hume não faz proselitismo da filosofia, porque entende que a maioria dos homens sabe encontrar ocupações condizentes com a importância que dão a suas vidas. O problema é quando a religião ou a filosofia querem lhes explicar qual é o valor que devem atribuir às coisas, pois no afã de generalização elas aumentam ou depreciam demais esse valor. $\mathrm{O}$ caso de Pascal é paradigmático, pois revela bem as duas posições que ele visa combater. Para Pascal, o homem pode apostar para ganhar tudo, porque não tem nada a perder; ele é absolutamente miserável, mas tem a possibilidade de ganhar uma grandeza infinita, ganho que passa, sobretudo, pelo reconhecimento de sua miséria. ${ }^{59}$ Para Hume, a aposta pascaliana talvez não se caracterize bem como uma aposta ou como um jogo segundo os princípios que a própria filosofia de Pascal havia admitido. As regras do jogo são muito complexas, o jogador não empenha absolutamente nada de início e ganha tudo numa rodada só, o desenrolar da partida é curto demais e não se pode dizer que nela se aprenda o fundamental, que é aprender a jogar.

A condenação dessa atitude de extremos simbolizada por Pascal não significa, como se vê, frivolidade da parte de Hume. Aliás, ele não se esquece de lembrar que a frieza pode vir justamente de um desdém filosófico altaneiro pelas coisas humanas, desdém que logo se transforma quando é a vida do "filósofo sublime" que está em jogo:

Enquanto os outros jogam, ele admira sua aplicação e ardor; mas tão logo faz uma aposta, é transportado pelas mesmas paixões que antes condenava como mero espectador. ${ }^{60}$

\section{Referências bibliográficas}

DELEUZE, G. Empirisme et subjectivité. Essai sur la nature humaine selon Hume. Paris: PUF, $3^{\mathrm{a}}$ ed., 1980.

58 Em seu livro sobre a inquietude, Jean Deprun fala ainda de um terceiro princípio, o da "amortização da inquietude pela ficção" ou princípio de irrealidade. Esse princípio também está presente na obtenção de prazeres estáveis e seguros em Hume, sendo importante na conversão das paixões fortes em paixões fracas, mais especificamente ainda na passagem da delicadeza de paixão à delicadeza de gosto.

59 "Toutes ces misères-là prouvent sa grandeur. Ce sont misères de grand seigneur, misères d'un roi dépossédé." Pensées, 107, p. 575.

60 "O Cético", trad. cit., p. 141. 
DEPRUN, J. La philosophie de l'inquiétude en France au XVIII siècle. Paris: Vrin, 1979.

DU BOS, J.-B. Réflexions critiques sur la poésie et sur la peinture. Paris: École Nationale Supérieure des Beaux-Arts, 1993.

LOCKE, J. An Essay concerning Human Understanding. In: The Works of John Locke. Londres: Routledge/Thoemmes Press, 1997.

HUME, D. A Arte de Escrever Ensaio. São Paulo: Iluminuras, 2011.

. An Enquiry concerning Human Undestanding. Edição de Selby-Bigge, revisão

de P. H. Nidditch. Oxford: Clarendon Press, 1992. Tradução para o português de José Oscar de Almeida Marques. São Paulo: Editora da Unesp, 2003.

. A Treatise of Human Nature. Edição de Selby-Bigge, revisada por P. H.

Nidditch. Oxford: Clarendo Press, 1978. Tradução para o português de Déborah Danowski. São Paulo: Unesp - Imprensa Oficial, 2000.

MALHERBE, M. "Un roman philosophique". In: HUME, D. Système sceptique et autres systèmes. Paris: Seuil, 2002.

MAUZI, R. L'idée du bonheur dans la philosophie et la pensée française au XVIIIe siècle. Paris: Armand Colin, 1969.

MONTAIGNE, M. Essais. Edição de Pierre Michel. Paris: Gallimard, 1962.

MONZANI, L. R. Desejo e Prazer na Idade Moderna. Campinas: Editora da Unicamp, 1995.

PASCAL, B. Pensées. In: Oeuvres Complètes. Edição de M. Le Guern. Paris: Gallimard, 2000, vol.2.

POPKIN, R. H. "David Hume: His Pirrhonism and His Critique of Pyrrhonism". In: The Philosophical Quartely, vol. 1, n. 5, oct. 1951.

THIROUIN, L. L'hasard et les règles; le modèle du jeu dans la pensée de Pascal. Paris: Vrin, 1991. 